УДК 821.163.41.09 Стефановић Венцловић Г. https://doi.org/10.18485/godisnjak.2017.12.1

Томислав Ж. Јовановић* Универзитет у Београду Филолошки факултет
Оригинални научни рад

Примљен: 6. 10. 2017.

Прихваћен: 23. 10. 2017.

\title{
ДЕЛА АПОСТОЛА ТОМЕ У ИНДИЈИ У ПРЕРАДИ ГАВРИЛА СТЕФАНОВИЋА ВЕНЦЛОВИЋА
}

\begin{abstract}
У овом раду говори се о варијанти апокрифа који се тиче дела апостола Томе у Индији. Одлика те варијанте испољава се у мотиву апостоловог зидања небеске палате и сачувана је у осам српскословенских преписа и у једном на народном језику, у преради Гаврила Стефановића Венцловића. Венцловићев народни језик доноси архаичну лексику уз слој страних речи, од којих преовлађују турцизми. Начин на који је преуредио текст апокрифа говори о настојању да поједностави израз и приближи га народном разумевању. Уз рад прилаже се приређен текст Венцловићеве прераде апокрифа.
\end{abstract}

Кључне речи: апокриф, апостол Тома, Гаврило Стефановић Венцловић, небеска палата, текст.

Међу новозаветним апокрифима посвећеним Христовим апостолима посебно место заузимају дела која се тичу живота апостола Томе (в. Anoкрифи. Новозаветни. 2005). Она су настала на грчком језику и временом преведена на словенски, на коме су се сачувала у знатном броју (в. Отеро 1997). Са изразитијом наративношћу истичу се два донекле блиска, али умногоме различита апокрифа, који говоре о делима апостола Томе у Индији. Најупечатљивији мотив у једном од њих јесте царево кажњавање апостола дерањем коже због ширења хришћанске вере. Други апокриф одликује се мотивом апостоловог зидања небеске палате. Први апокриф

\footnotetext{
*tomjovan1@gmail.com
} 
познат је у две верзије, у дужој и краћој. Дужа верзија налази се у четири следећа српска преписа: препис друге половине XIV века, Москва, Руска државна библиотека, збирка Виктора Ивановича Григоровича, број 22; ${ }^{1}$ препис из 1409. године, Београд, Народна библиотека (стара збирка), број 828, 216a-234б; препис XV века, Београд, Универзитетска библиотека „Светозар Марковић”, збирка Владимира Ћоровића, број 30, 101а-115а; препис настао око 1550. године, Београд, Музеј Српске православне цркве, Збирка Радослава Грујића, број 219, 124б-134б. Краћа верзија сачувала се у следећа два преписа: препис из 1520. године, Архив ХАЗУ, број IV a 24, 28б-32a; ${ }^{2}$ препис почетка XVII века, Београд, Народна библиотека Србије, број 673, 96б-112б (непотпун на крају).

Други апокриф познат је у седам следећих српскословенских преписа: препис из 1320/30. године, манастир Хиландар, број 644, 19б-24a; ${ }^{3}$ препис XIV века, Београд, Народна библиотека Србије, број 637 (стара збирка), 125а-136б (непотпун); ${ }^{4}$ препис последње четвртине XIV века, Загреб, Архив ХАЗУ, број ІІІ ц 24 (Михановић број 23), 105а-109б; XIV век, Софија, Народна библиотека „Климент и Методиј”, број 1039, 175а-182б; препис из 1409. године, Београд, Народна библиотека Србије, број 828 (стара збирка), 216a-234б; XV век, Београд, Универзитетска библиотека „Светозар Марковић”, збирка Владимира Ћоровића, број 30, 96а-101а; препис из 1614-1625. године, Београд, Народна библиотека Србије, број 59 (Панагирик грешнога Дмитра), 165a-168а. Поред ових преписа издваја се један који је прерадио и исписао на народном језику 1732. године Гаврило Стефановић Венцловић у оквиру Поученија и слова за месеце септембар и октобар. Рукопис се налази у Старој збирци Архива Српске академије наука и уметности у Београду са сигнатуром 271, а препис Дела је на страницама 200а-209б (в. Стојановић 1901).

Држећи се свог начина преношења састава са српскословенског и рускословенског језика на српски народни језик, Венцловић је тако по-

${ }^{1}$ Препис објавио Ватрослав Јагић: V. Jagić, Novi prilozi za literaturu biblijskih apokrifa, Starine JAZU, V, Zagreb 1873, 96-108.

${ }^{2}$ Ватрослав Јагић је уз издање апокрифа из Григоровичеве збирке испод основног српскословенског текста донео и ову нешто скраћену варијанту на народном језику: V. Mošin, н. д., 71-72. Овај препис штампао је касније у оквиру читавог зборника Милан Решетар: М. Решетар, Либро од мнозијех разлога. Дубровачки ћирилски зборник од г. 1520, СКА, Зборник за историју, језик и књижевност српског народа, Прво одељење, Споменици на српском језику, књ. XV, Ср. Карловци 1926, 43-47.

${ }^{3}$ Препис објављен у: Т. Јовановић, ,Дела апостола Томе у Индији” према хиландарском рукопису XIV века, Археографски прилози, 20, Београд 1998, 41-53.

${ }^{4}$ Препис објавио Стојан Новаковић: S. Novaković, Apokrifi jednoga srpskog ćirilovskog zbornika XIV. vieka, Starine JAZU, VIII, Zagreb 1876, 69-74. 
ступио прилагођавајући и Дела апостола Томе у Индији. Њему није било довољно само да „преточи” текст са једног вида језика на други, него и да прошири поједине делове објашњавајући оно што је сматрао да треба додатно приближити пре свега народном слушаоцу. Поред тога, он је за ову прилику спојио два сасвим одвојена дела. Најпре је на почетку увео краће синаксарско житије апостола Томе. Очигледно је и наслов читавог

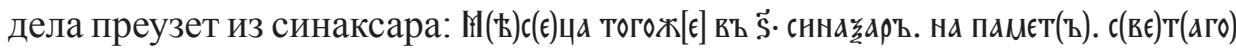
aп(o)c(то)ха ө.онн. После синаксарске целине уследила су апокрифна Дела апостола Томе у Индији. Како би повезао једно са другим, Венцловић је после синаксарског житија уметнуо реченицу која најављује шири сиже. Тај додатак има призвук усменог народног приповедања: „Ама, пређе тога, јоште за живота док је био, згоди му се пут." Судећи према српскословенским преписима, уочљиво је да се поред проширења садржине, у неким случајевима сажима затечени текст. Тако је код Венцловића изостао знатан део на почетку у коме се говори о одређивању где ће који апостол ићи да проповеда Христово учење, као и сцена о продаји апостола Томе индијском трговцу. Осврт на остале делове који се садржински приближавају показује врсту Венцловићевог одступања, са одликама сажимања или проширивања. Кроз епизоду о доласку апостола са трговцем у индијски град у коме старешина удаје своју кћер и позива све грађане и странце на свадбу сагледава се Венцловићев однос према изношењу садржине.

\begin{tabular}{|c|c|}
\hline Хиландар 644 & Венцловић \\
\hline 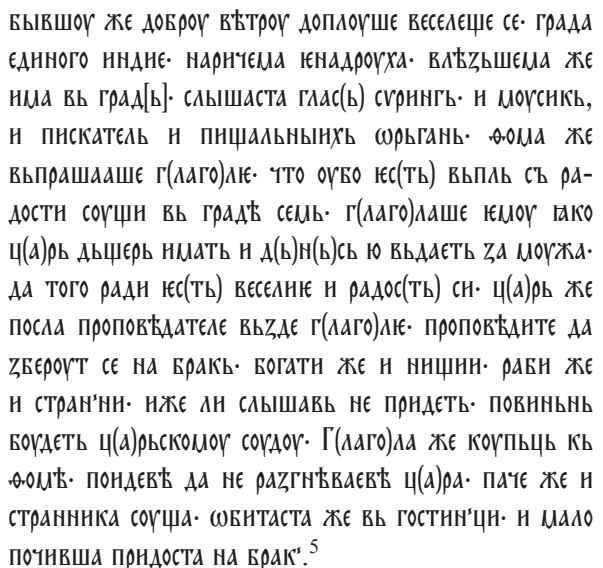 & 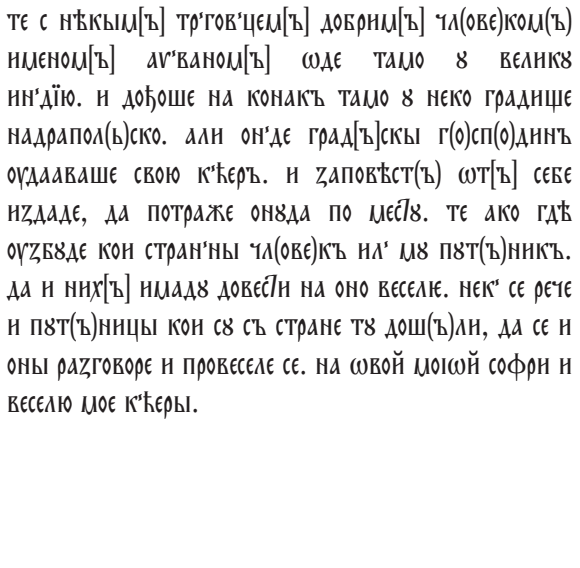 \\
\hline
\end{tabular}

${ }^{5}$ Преузето из издања: Т. Јовановић, ,Дела апостола Томе у Индији” према хиландарском рукопису XIV века, 47. 
Наспрам показаног примера сажимања, постоје делови у којима Венцловић проширује затечену фабулу. Сусрет апостола Томе са индијским царем и њихов договор око зидања палате код Венцловића је нешто детаљнији него у српскословенском тексту:

\begin{tabular}{|c|c|}
\hline Хиландар 644 & Венцловић \\
\hline 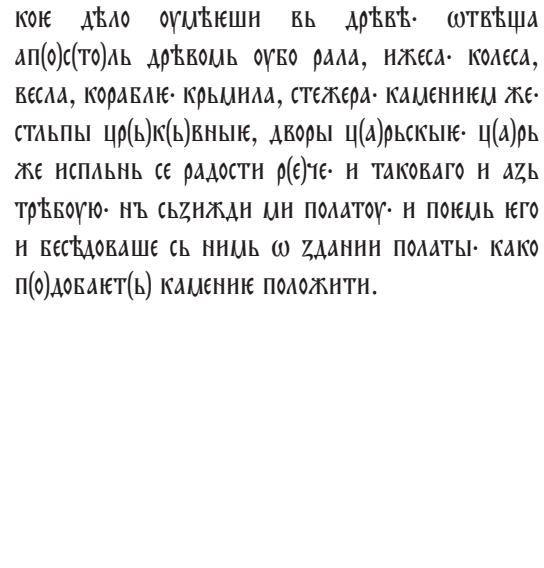 & 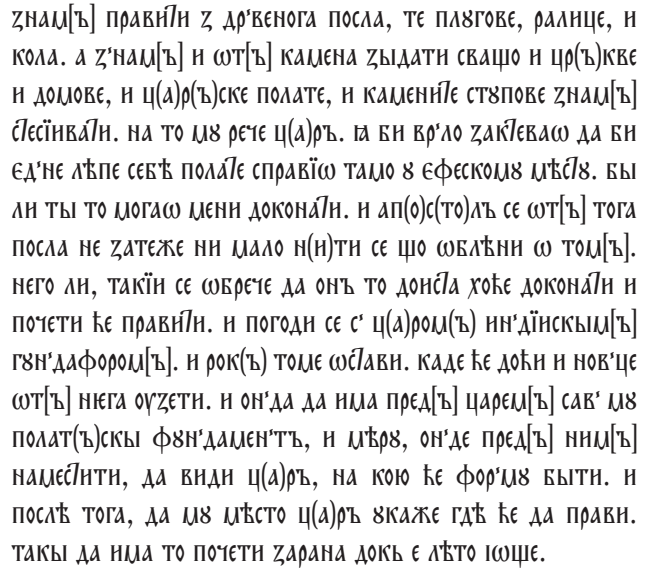 \\
\hline
\end{tabular}

Овако различит Венцловићев приступ обликовању текста део је његовог поступка који је неговао у делима која је преносио на народни језик. У томе је, између осталог, његова посебност. Поред тога, од изузетног значаја јесте народни језик који је Венцловић увео у прераде низа дела распоређених по обимним зборницима. Лексика коју је користио припада свакако његовом говору (в. Ивић 1997). То показује низ коришћених локализама и архаизама са облицима из ранијих епоха, од којих су се неки и до данас задржали у појединим народним говорима: вює $[\mathrm{b}]$ (мада и вєz[ъ]), гАҚаы, гАҚА[ъ] досТайннцц, єєр'но (као и єръ, Ієр), защоно (поред zащо), нмадв, кал (у значењу као), І се и кога), коп'ґан, коюно (поред кою), коџвє, кунгй, мєдє (У значењУ мииљьаше), мнҚАє, нахлнч8, намн (поред нама), напрє (мада и нан̆посль), нейма (поред нє нма,

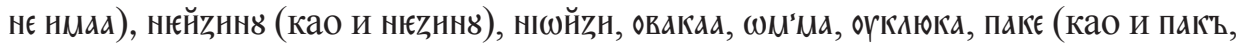

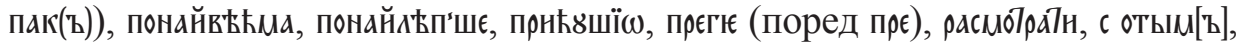

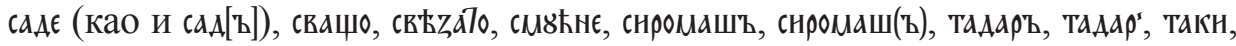
такїн, такІн, такы, томв (поред томє), ц(а)ром(ъ) (поред царєм[ъ]), чоно (као и що).

Једна од одлика Венцловићевог народног језика тиче се коришћења слова $x$. Овај знак је најчешће присутан на местима на којима се и очекује. 


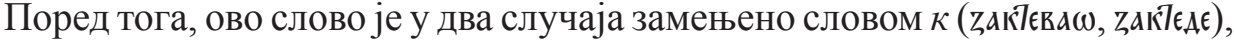

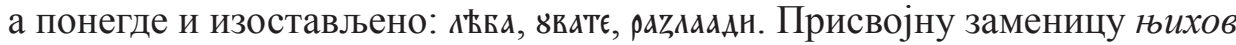
срећемо у уобичајеном изгледу (ннхова), али и прилагођеној народном облику ннном[ъ].

Слово јат налази се у овом саставу у прилично правилној употреби. Само понекад оно је замењено екавском варијантом у следећим речима:

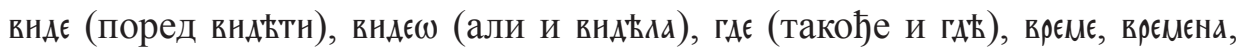
донетН, намеटТнтн, и рьтъ), товєкъ. У једном случају Венцловић је одступио од ове праксе и исписао ијекавски облик вїашє, који је вероватно понео из свог детињства проведеног у сремским крајевима пре него што је прешао у сентандрејске пределе.

Уз народну лексику и облике Венцловић веома ретко користи и српскословенске речи и облике. Само у некима од њих сачуван је потпун српскословенски изглед: въннма, въсхнщєн(ъ), съзІндаш, чл(овъ)къ. Поред ових појединачних случајева, Венцловић је једну целу молитвену реченицу задржао у српскословенском руху: вк[a]г[0]_ $[a] \rho 87 \epsilon$ Г(оспоА)н чи(овє)колюв'че. Облик ванннманю показује како је у српскословенској речи у првом слогу извршена вокализација (-вa), а на крају додат суфикс из народног језика (-ғуу).

Од значаја за историју српске ћирилице јесте појава Венцловићевог коришћења слова̄ $\hbar$ и $\hbar$, што је одвијало скоро читав век пре Вукове реформе азбуке. Венцловићево се обележавање гласа $\hbar$ помало је колебљиво. Тај глас означаван је углавном словом $\hbar$ : Браћа, вћћма, вњћъ, глҚАћн, доћн, zаповћсћ8, к'ћєръ, к'ћєрн, к'ћєры, наћн, нємоћннгке, ноћн, ов ћћа, показвюћн, просєћн, славєћн, ћє, ћєшъ, ћ8, хоћє, чнсооћн. Тек у неким примерима уместо овог слова глас $\hbar$ исказан је спојевима слова $\kappa$ и прејотованог $e$ :

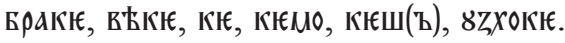

Мада је изглед Венцловићевог $\hbar$ и ђ веома сличан, ипак се ова два слова разликују. Обележавање гласа Ђ изведено је на четири начина. Нај-

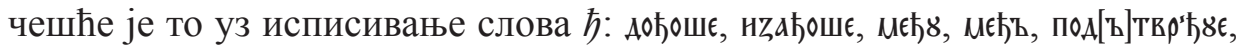
прођох[ъ], раzІнђє, рођєны, съzнђыва7н, оүђн. Упола мање случајева ознаке овог

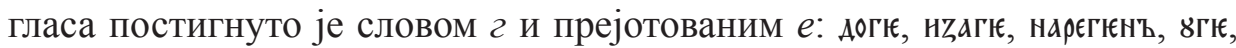
оүгіє. Тек по један пример означавања овог гласа изведено је помоћу слова 2 и прејотованих $a$ и $y$ : сьгғшє, мєгю. Запажа се да су понекад гласови $\hbar$ и $ђ$ обележавани на двојак начин приликом исписивања истих речи.

Појава удвајања појединих слова код Венцловића је знатно распрострањена. Међу таквим случајевима преовлађује самогласник $u$. Најчешће доминирају комбинације десетеричног и осмеричног $u$. Десетерично $u$ са 
две тачке среће се у следећим примерима: Б(0)жїн, Б(0)жїншй, градовїн, дарїнва̄7н, аругїн, zапїн7а (поред zапн7а), нн'дїнскв, нн'дїнскым[ъ], кр(ъ)стїн, мїнслїн (али и мыслн), напїнгай, начїннга(, он'даш'нїн, онїн (мада и онн), прїнднком[ъ], прїнднкв,

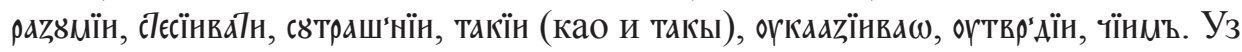
овакве спојеве Венцловић понекад исписује десетерично $u$ без тачке са осмеричним $u$ : вІн, запінта (као и zапнта), ннханской, нстін, иногінм[ъ] (поред

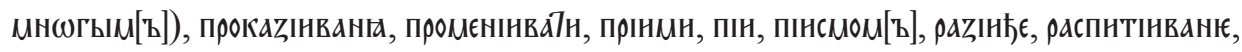
съzІндас, такІн (мада и такн), талІнра, тІнм[ъ], цінпом[ъ]. Само у једном случају исписана су два десетерична $u$ у две варијанте: в(о)жїıюй. Иако Венцловић користи слово $j(\breve{H})$, удвојена слова $u$ у ретким случајевима имају гласовно оправдање како би се другим од тих слова означио овај глас. Случајеви ван те улоге представљају неку врсту раније српскословенске праксе исписивања удвојених слова.

Од удвојених самогласника налазимо још и $a$ : Адаванғє, А(оү)шєв(ъ)наа,

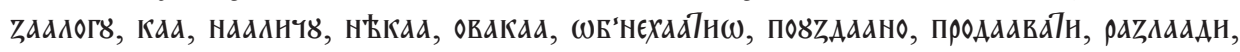

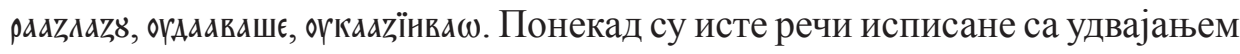
овог самогласника, а понекад је та појава изостајала: Блдага : Блдга, нщда :

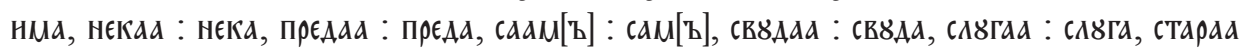
: стара, тал : та, вкааъв : вкажє, вкадъъ : вказаш.

Речи са удвојеним сугласницима веома су ретке. Налазимо их у речи грчког порекла ангел онако како је било уобичајено да се она пише алфавитом: $а г \Gamma(\epsilon) \Lambda \mathrm{z}, \operatorname{aгr(\epsilon )\Lambda а.~Понекад~је~присутно~и~удвојено~} H$, које увек има пајерак између: нєпорвшєн'номв, нєпромен'но, нєрвкотворєн'нє, стран'наго, стран'ны. Само у једној речи налазимо ижицу са истом гласовном вредношћу као и слово в уз које стоји: аү'ваном[ъ].

Међу страним речима које је Гаврило користио преовлађују турцизми који су се до тог времена увелико одомаћили у говору из кога је потекао:

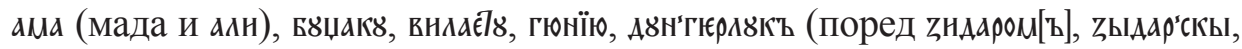
zыдатн), уз ову реч такође и неймаръ, неймар(ъ), конакъ, (ББаш'ка, софрє, софрн, софрв, тєкє, ХаБаръ. У неколико наврата он користи немачку реч мајстор и њене изведенице: майсторъ, майсторїю, майстор'скв, майсорско. Очигледно је да су и речи латинског порекла фор'ив, фвн'Адмен'тъ биле у уобичајеној употреби.

Иу овом саставу Венцловић је показао сву умешност да већ постојеће дело, затечено на српскословенском језику, или можда и у руској варијанти, преточи на народни језик користећи наративне моделе усменог казивања, које је познавао у свој раскоши. Народни језик којим је прерадио велики број дела неизмерно је благо које заслужује обухватнија проучавања.

У додатку се доноси приређен текст Венцловићеве прераде Дела апостола Томе у Индији из 1872. године из Архива САНУ у Београду, број 271. 


\section{ЛИТЕРАТУРА}

Апокрифи. Новозаветни. 2005: Приредио и на савремени језик пренео Томислав Јовановић, Библиотека Стара српска књижевност у 24 књиге, књига 23, II том, Београд: Просвета - Српска књижевна задруга.

Јагић 1873: V. Jagić, Novi prilozi za literaturu biblijskih apokrifa, Starine JAZU, V, Zagreb, 96-108.

Јовановић 1998: Т. Јовановић, Дела апостола Томе у Индији, према хиландарском рукопису XIV века, Археографски прилози, 20, Београд, $41-53$.

Ивић 1997: П. Ивић, О дијалекту и пореклу Гаврила Стефановића Вениловића, Рачански зборник, 2, Бајина Башта, 15-19.

Новаковић 1976: S. Novaković, Apokrifi jednoga srpskog ćirilovskog zbornika XIV. vieka, Starine JAZU, VIII, Zagreb, 69-74.

Отеро 1978: A. de Santos Otero, Die handschriftliche Überlieferung der altslavischen Apokryphen, 1. Berlin, 85-96.

Решетар 1926: М. Решетар, Либро од мнозијех разлога. Дубровачки ћирилски зборник од г. 1520, СКА, Зборник за историју, језик и књижевност српског народа, Прво одељење, Споменици на српском језику, књ. XV, Ср. Карловци, 43-47.

Стојановић 1901: Љ. Стојановић, Каталог рукописа и старих штампаних књига, Збирка Српске краљевске академије, Београд, 96.

Томислав Ж. Йованович

\section{ДЕЯНИЯ АПОСТОЛА ФОМЫ В ИНДИИ В ОБРАБОТКЕ ГАВРИИЛА СТЕФАНОВИЧА ВЕНЦЛОВИЧА}

Резюме

\footnotetext{
Среди новозаветных апокрифов, посвященных апостолам Христовым, особое место занимают произведения, относящиеся к жизни апостола Фомы. Они возникли на греческом языке и с течением веремени были переведены на церковнославянский, на котором сохранились в значительном количестве списков. Нарочитой повествовательностью отличаются два в некоторой степени близких, но во многом отличающихся апокрифа о деяниях апостола Фомы в Индии. Самым ярким мотивом в одном из них является наказание царем апостола Фомы за распространение христианской веры сдиранием его кожи. Второй апокриф отличается мотивом строительства апостолом небесного дворца. Первый вариант апокрифа сохранился в восьми списках сербского извода и в одном списке на народном сербском языке в обработке Гавриила
} 
Стефановича Венцловича. Его народный язык содержит архаичную лексику и пласт иностранных слов, среди которых преобладают турцизмы. Способ редактирования апокрифа свидетельствует о попытке упрощения языка и его приближения к пониманию народа. В приложении публикуется апокриф в обработке Венцловича.

Ключевые слова: апокриф, апостол Фома, Гаврил Стефанович Венцлович, небесный дворец, текст

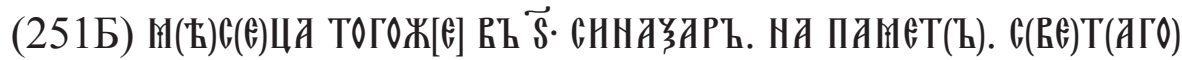

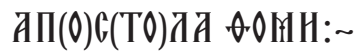

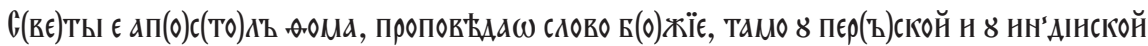

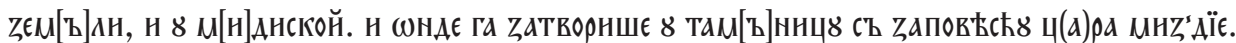
н зараА' тога крощо Мв є оүвЂрї

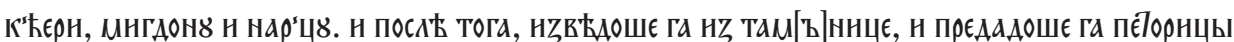

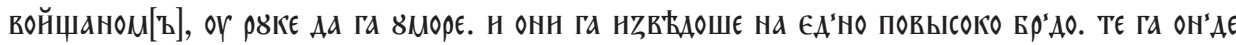

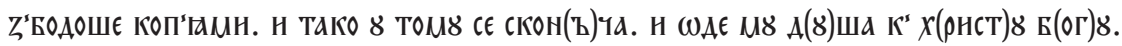

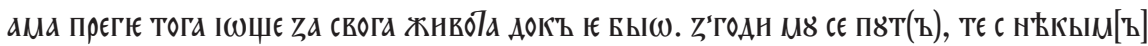

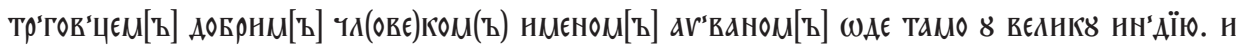

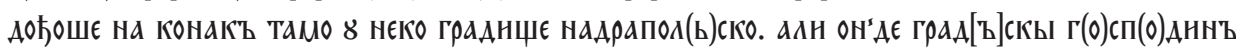

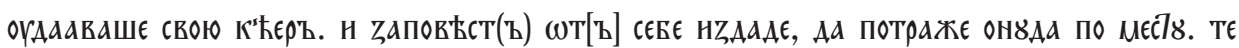

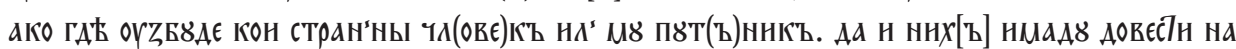

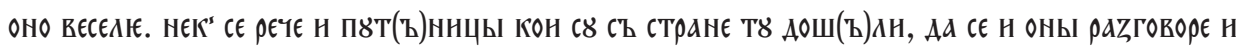

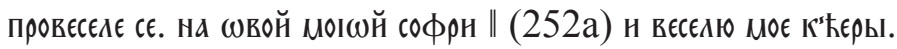

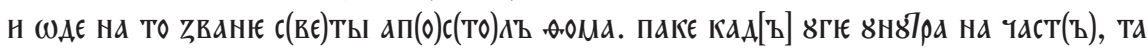

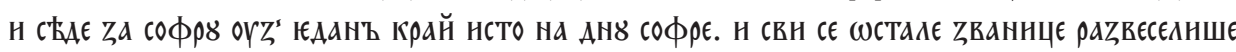

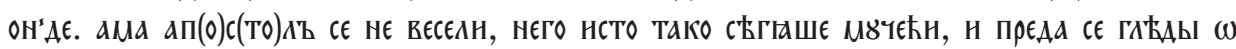

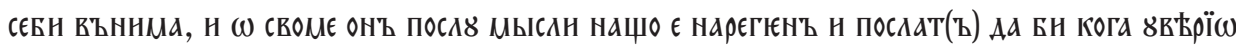

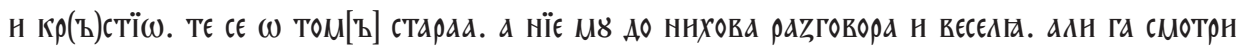

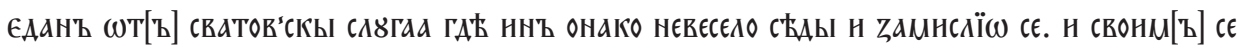

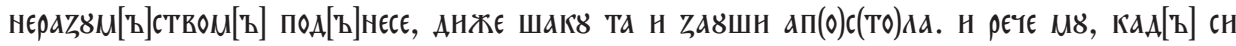

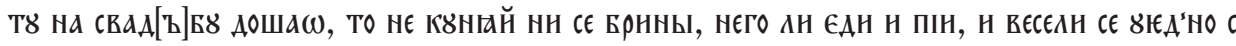
АюА[ъ]Ма, н напїннй $\kappa^{s}$ ннща.

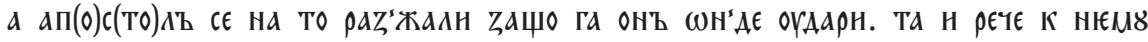

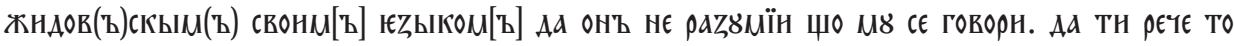

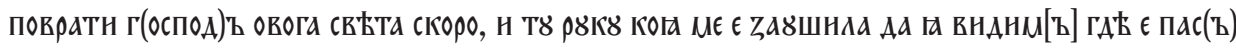
ПОБААЧН НА УКААZъ МнОГІНМ[ъ] АА ТО БУАє. 


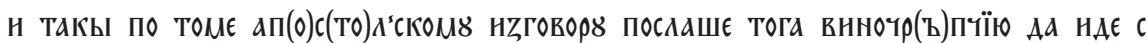

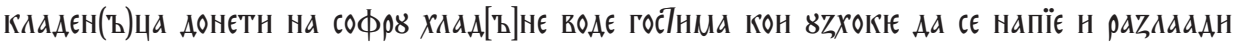

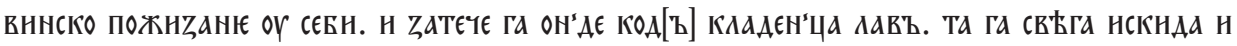

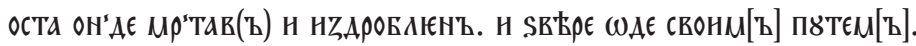

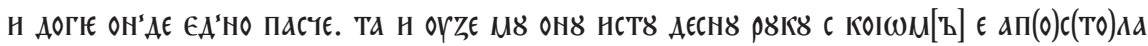

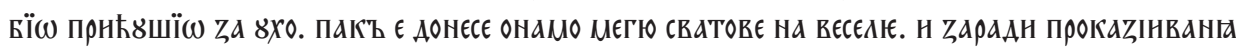

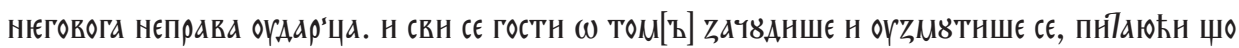

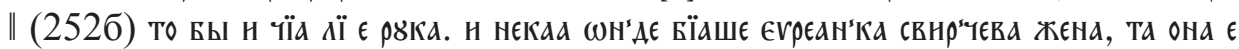

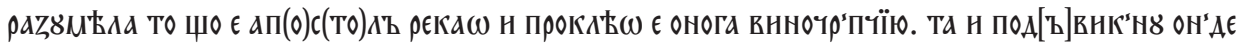

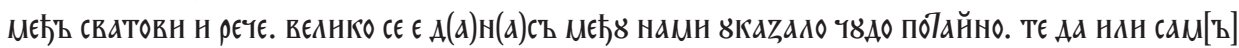

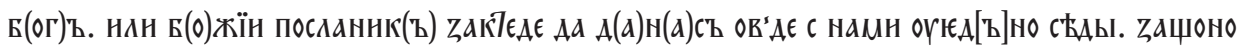

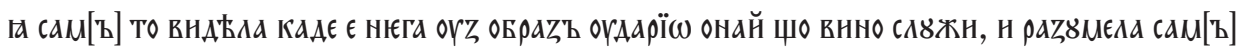

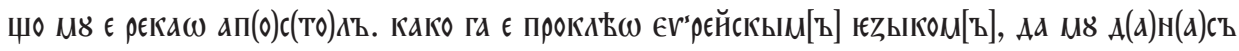

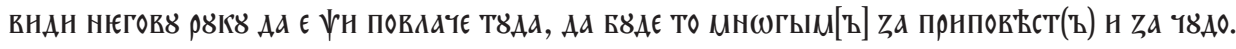

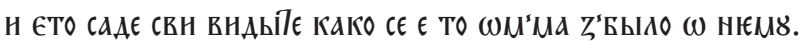

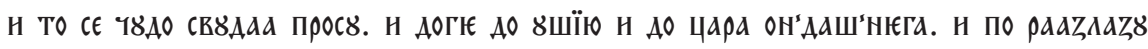

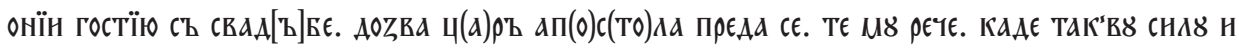

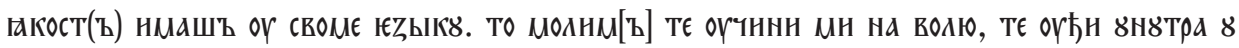

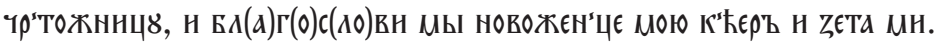

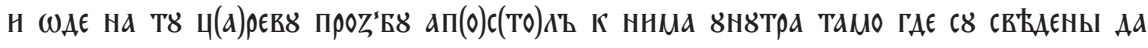

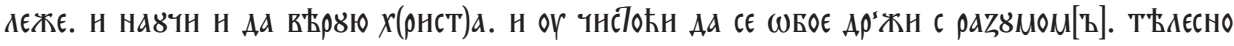
сМћШНване АА

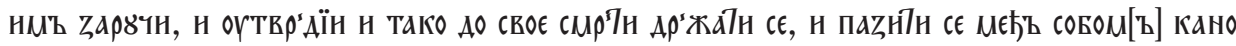

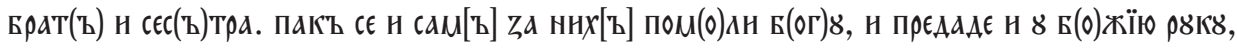

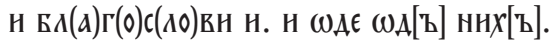

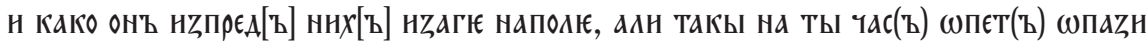

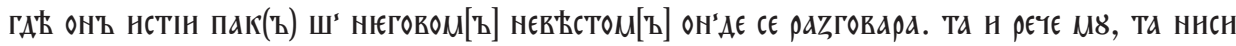

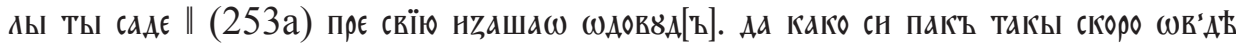
оүша $\omega$ н вратї $\omega$ сє оүнв

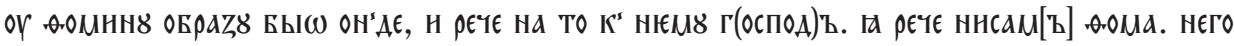

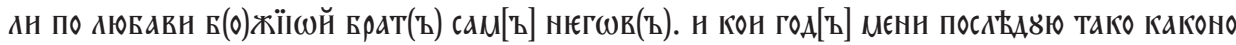

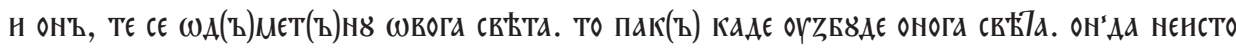

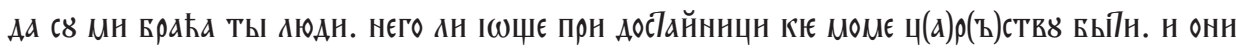

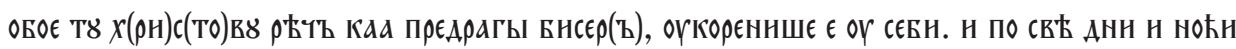

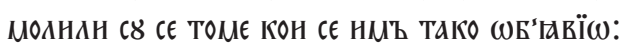

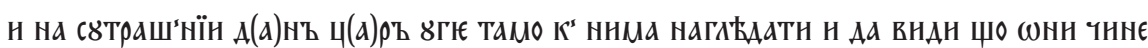
н МНАвю

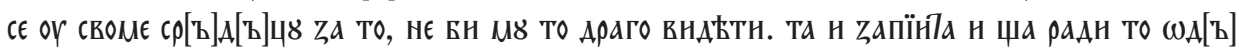

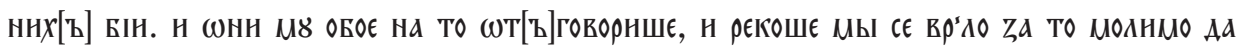




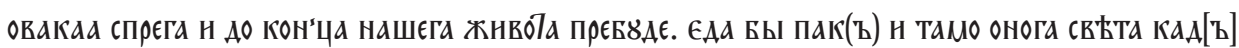

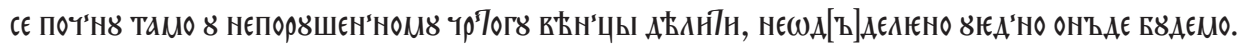
по вкаад৪ онога неZнан'ца стран'наго, чо сє є нам[ъ]

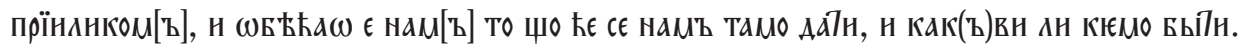
ако овако А'Ппо се до Крага 8 чнСТоћн 8Zар'Жнмо.

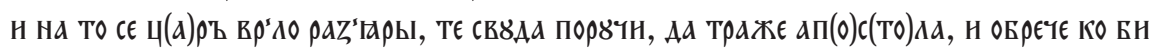

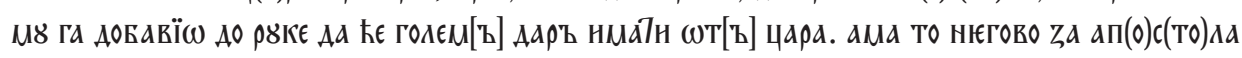

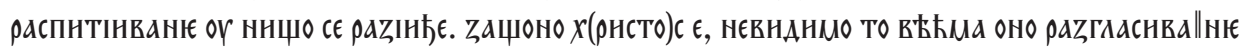

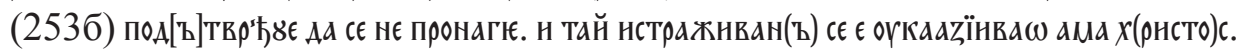

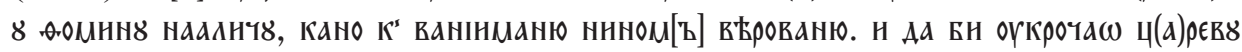

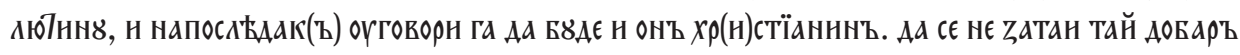

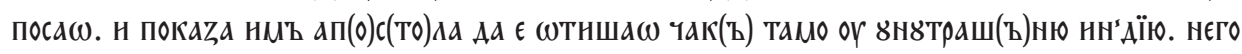

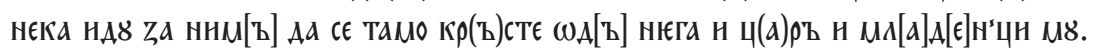

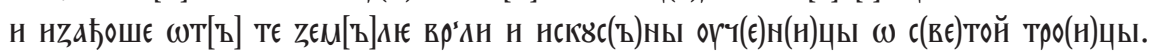

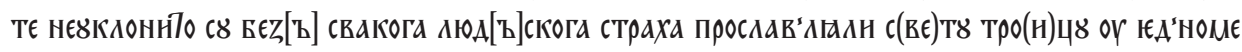

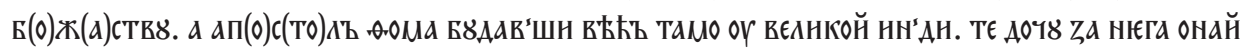

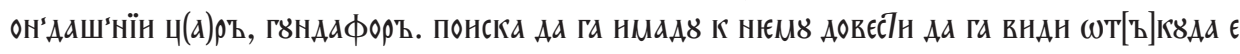

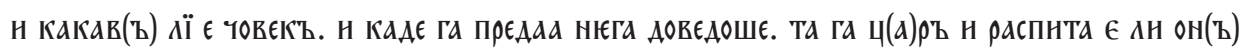

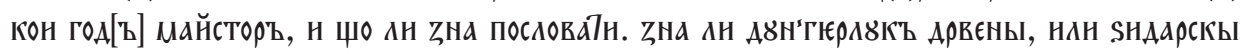

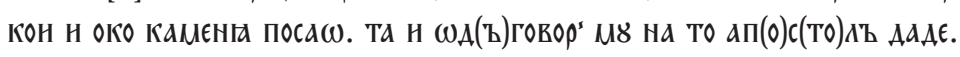

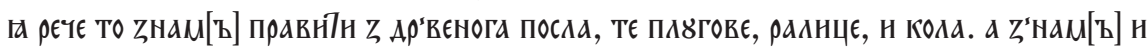

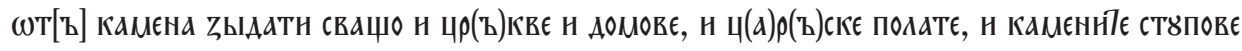
zнам[ъ] Сєєё̈нваТн.

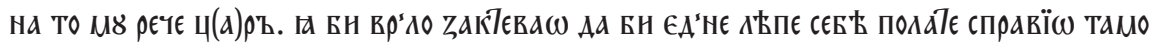

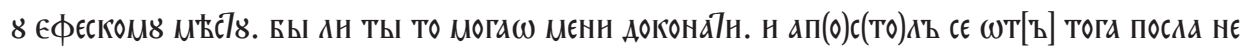

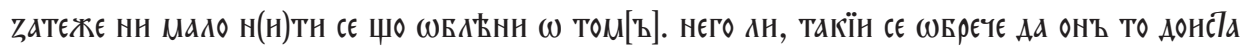

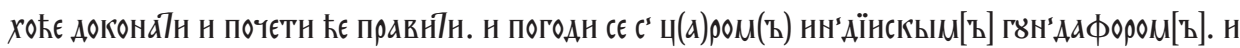

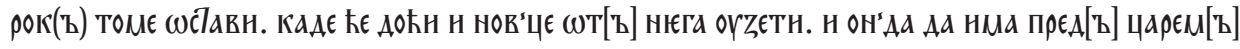

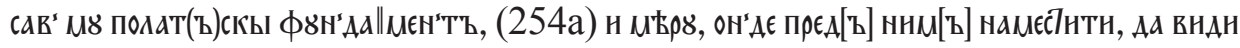

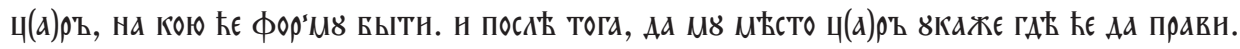

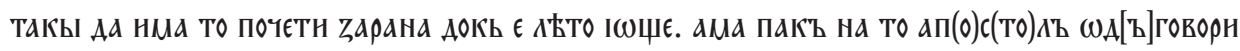

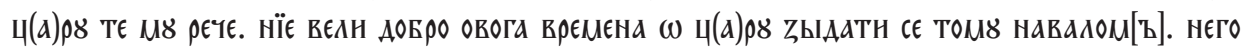

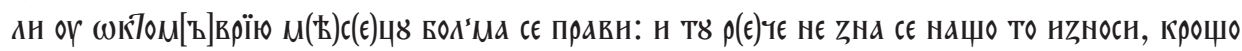

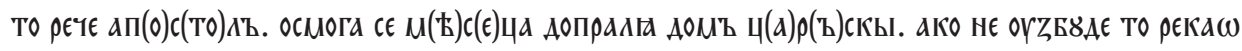

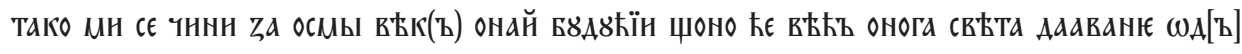

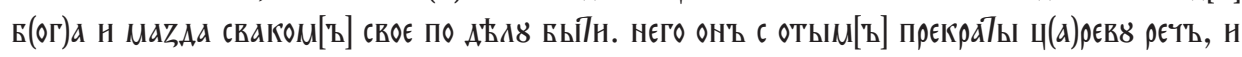

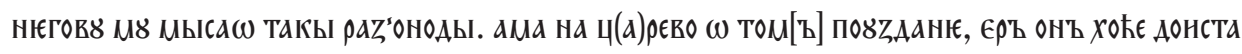

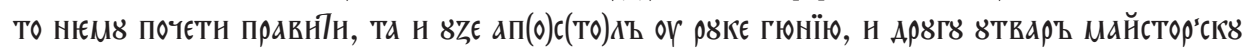

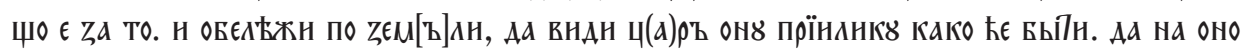




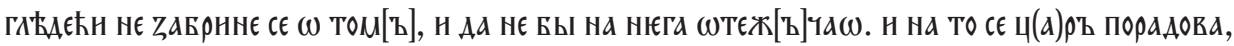

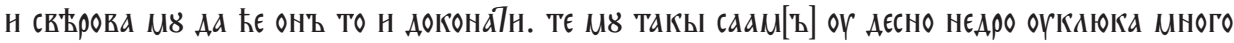

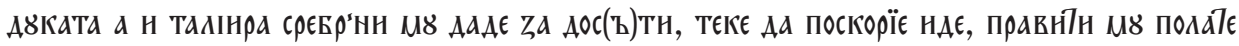

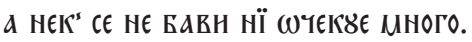

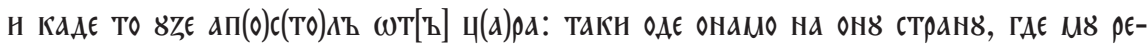

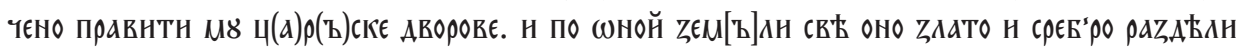

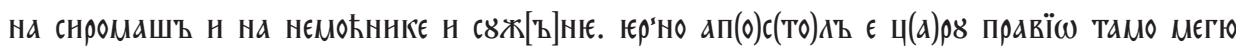

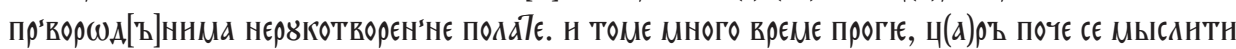

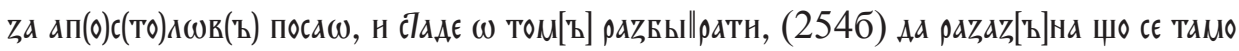

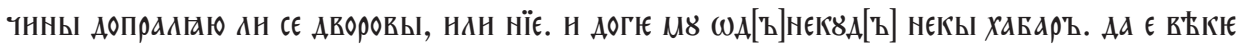

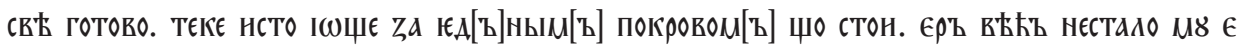
трош'Ка. н нє нмад н с с чїнщъ довр

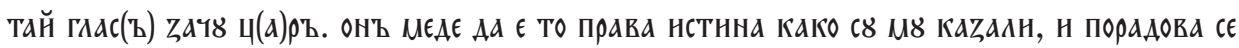

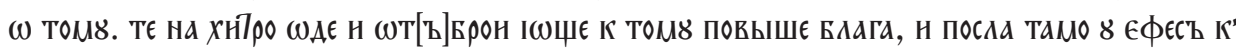

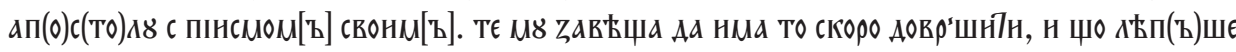

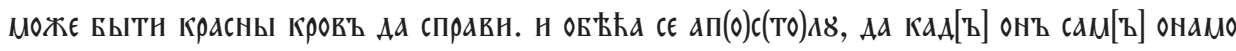

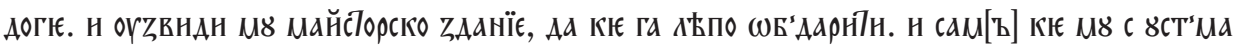
похвалнін неговУ майсторї̈:

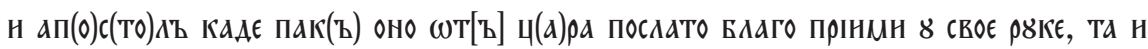

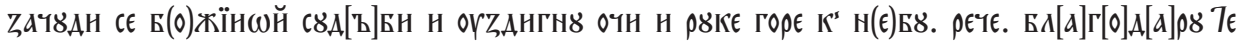

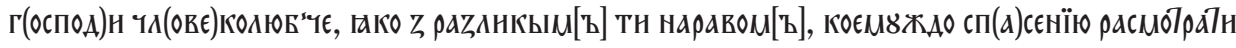

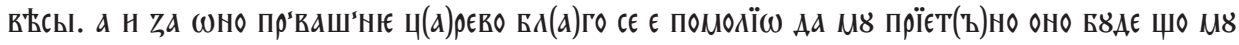
$\epsilon$ на снромаш(ъ) zа негов8 А(8)ш૪ вї тамо прос'таком[ъ].

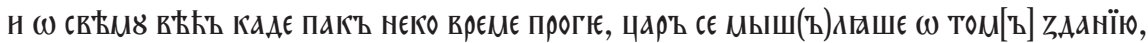

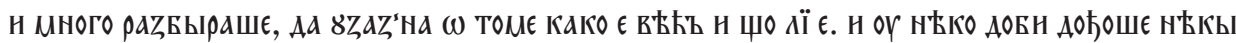

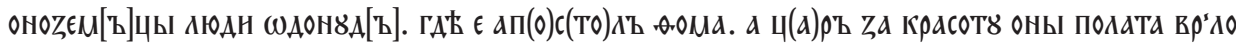

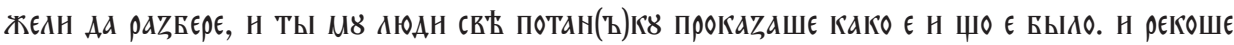

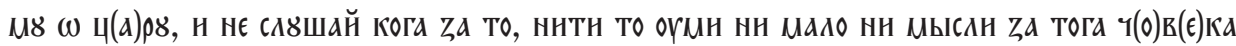

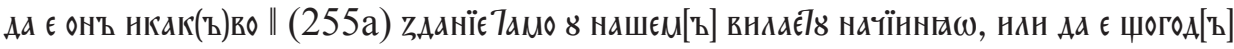

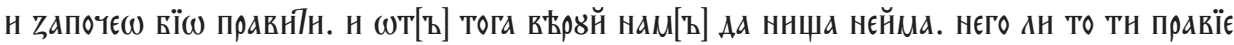

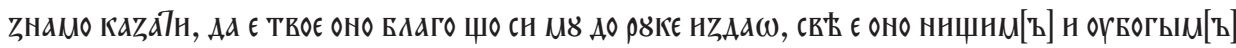

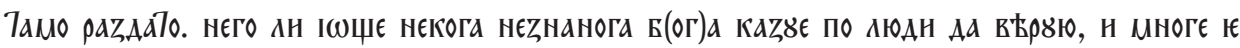

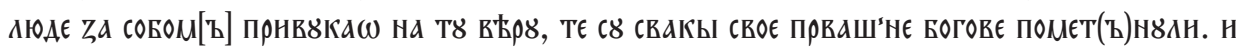

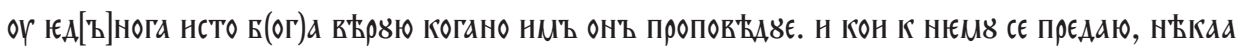

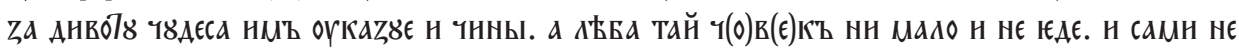
zнамо како се жнвы.

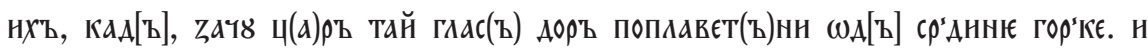

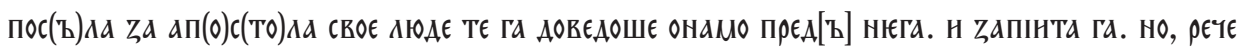


М४ ЧО ४чНны ЄСН АН МЫ спрАвї

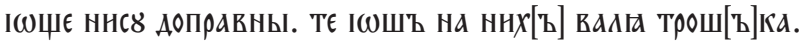

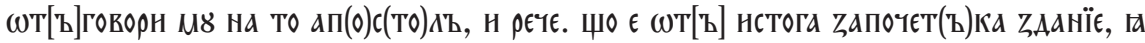

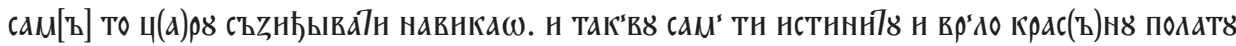

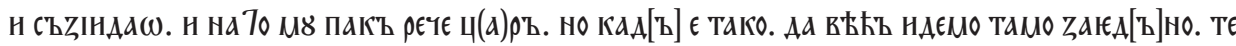

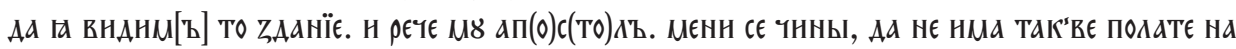

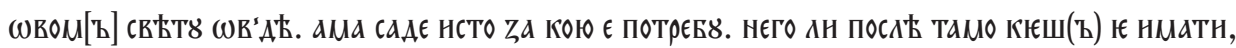

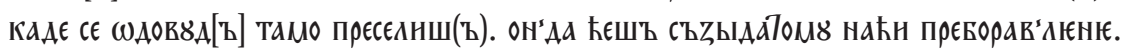

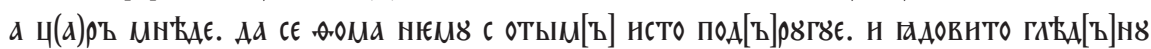

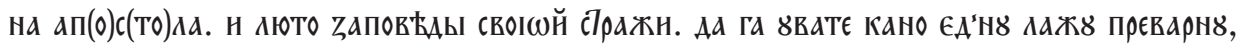

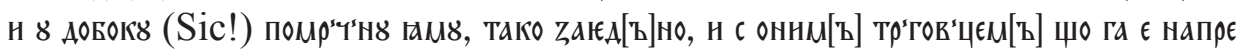

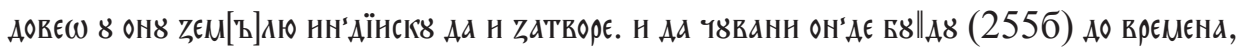

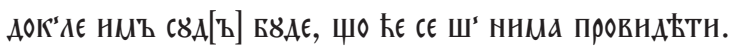

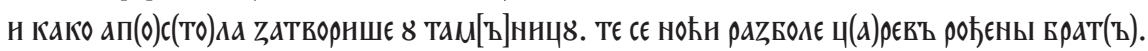

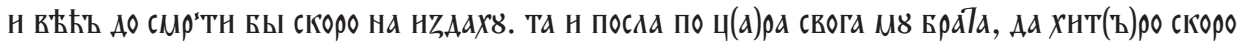

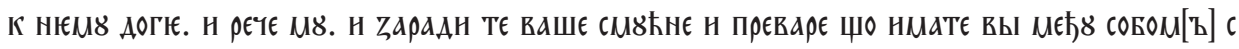

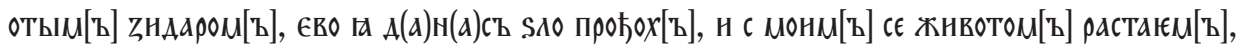

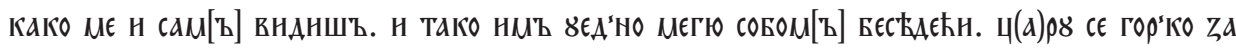

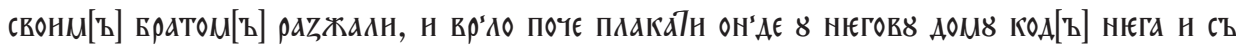
Свїн СвоН БОАгрН.

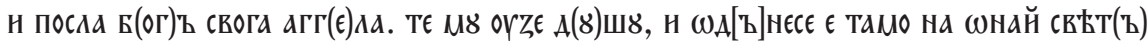

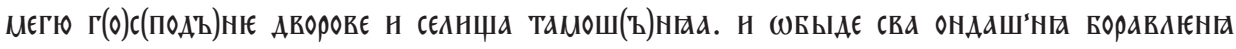

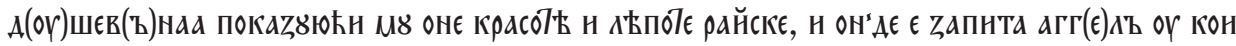

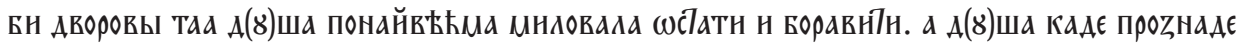

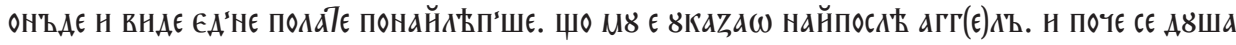

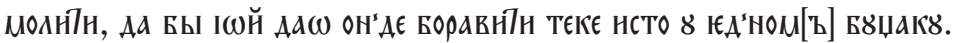

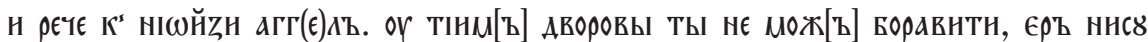

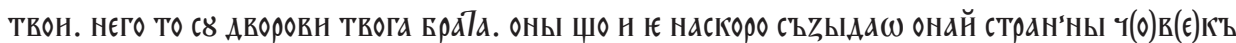

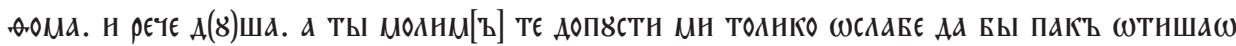

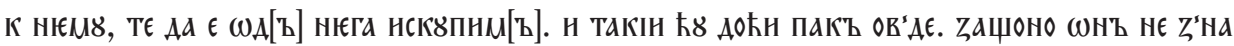

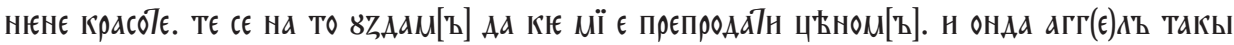

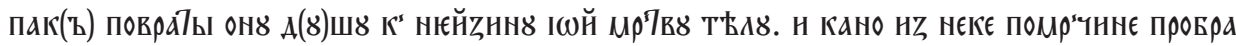

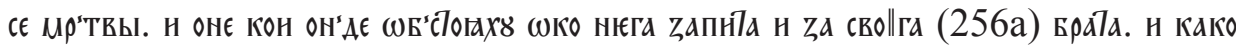

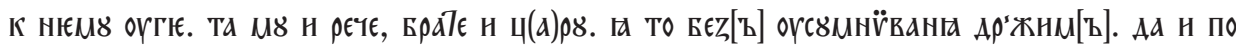

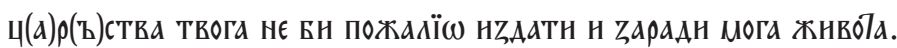

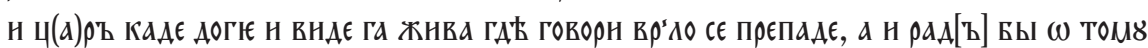
ГАє М૪ пак(ъ)

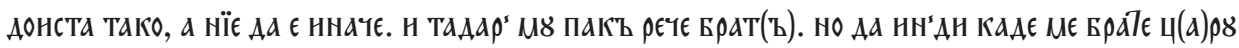

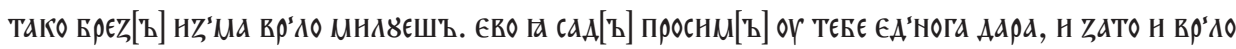


7Н се МолнМ[ъ] Аа Бн Менє

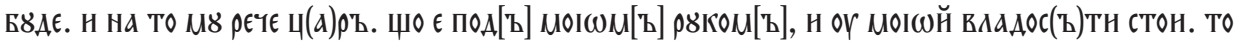

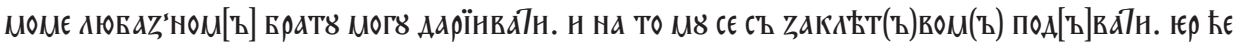

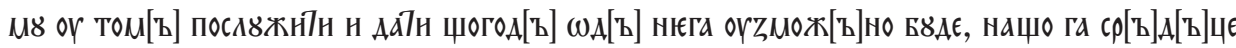

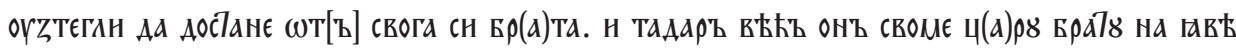

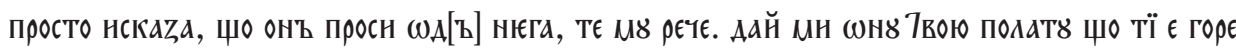

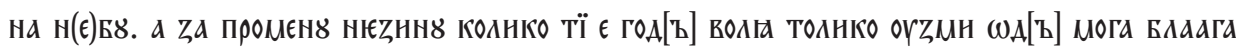

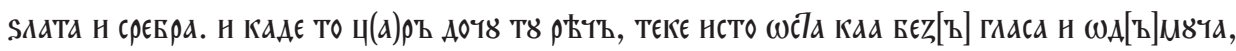

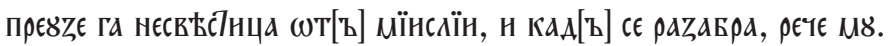

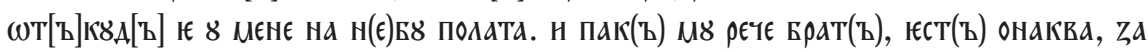

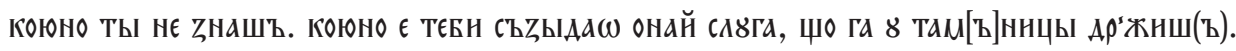

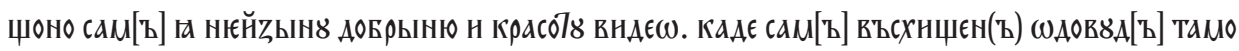
Бы $\omega$, н теБє сєМ[ъ] Брнгом[ъ]

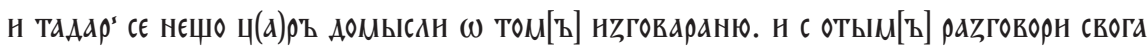

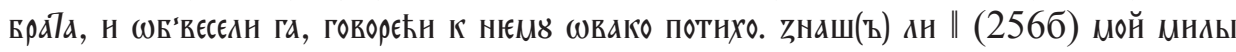

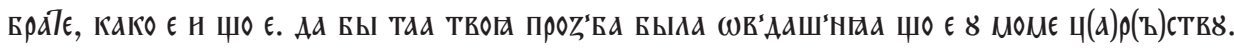

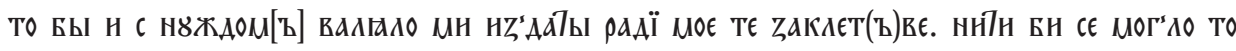

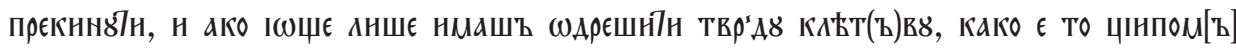

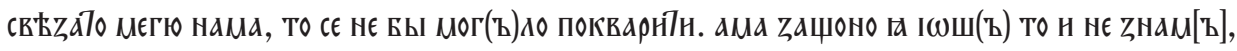

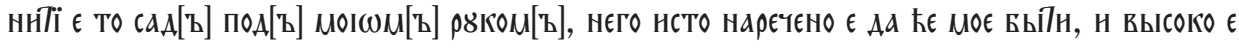

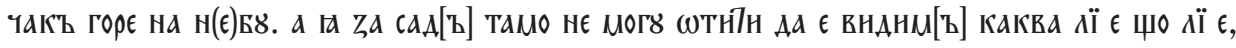

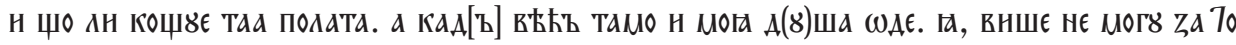

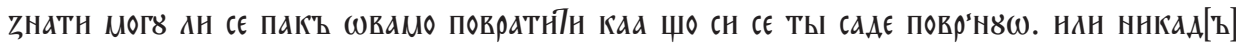

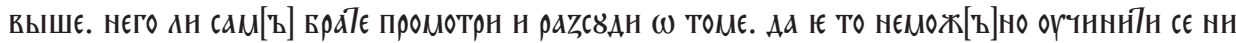

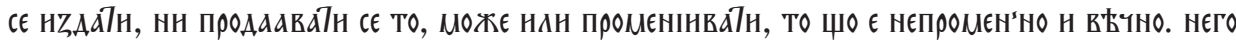

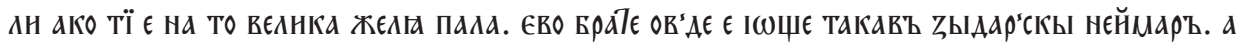

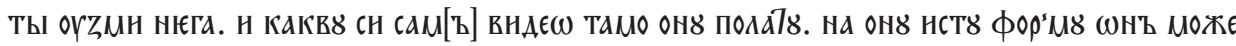
ТеББ онамо сПравнНН.

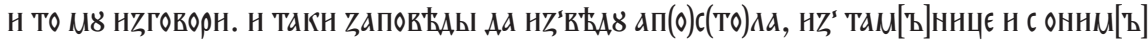

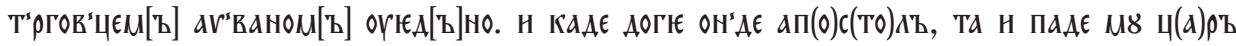

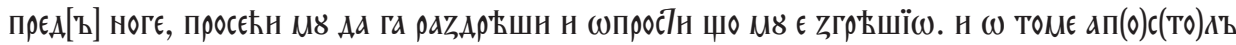

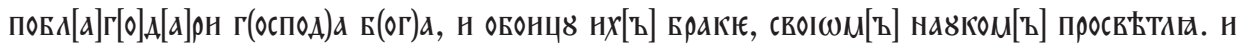

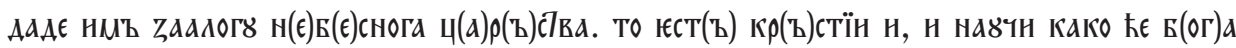

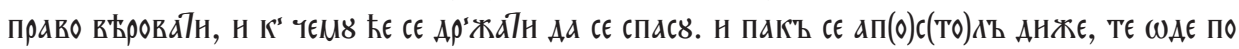

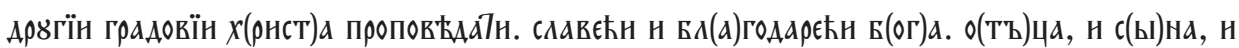
с(вє)таго д(8)ха: $\omega$ свїн поспьшєннх[ъ] єговынх[ъ]. 